\title{
Immigrant Employment in the Slovak Hospitality Industry: Profiles, Experience, and Education
}

\author{
Andrej Př́ívara \\ Faculty of National Economy, University of Economics in Bratislava, Bratislava, Slovakia \\ Andrej Kiner \\ Faculty of International Relations, University of Economics in Bratislava, Bratislava, Slovakia \\ Received: 11 October 2020. Revision received: 15 November 2020. Accepted: 24 November 2020
}

\begin{abstract}
The hospitality industry is dependent on migrant employees. This statement is also valid for Slovakia, where the percentage of migrant workers rose in recent years. This research seeks to answer whether part-time and full-time applicants are overqualified and, if so, to examine whether male and female applicants tend to be overqualified using Pearson's chi square test, focusing on the likelihood of overqualification in both genders. Drawing from the immigrant hospitality applicants' CVs, which were collected and examined, the paper strives to explore their profiles and previous experience in the hospitality industry, but mainly to analyse the education they have attained. The data were collected through quantitative methods, comprising CV analysis and netnography. The analysed CVs were obtained randomly from a job recruiting and advertising domain in order to achieve the maximum objectivity possible. The findings show the majority of applicants to be of Ukrainian and Serbian nationality. Most of the international candidates possess appropriate knowledge of the Slovak language and already have work experience in the hospitality sector. More applicants were attained that had a tertiary education than with secondary education only. Thereby, the results suggest a tendency for migrant applicants to be overqualified regardless of their sex while presenting possible insights into the researched issues.
\end{abstract}

Keywords: migrants, hospitality industry, education, Slovakia

JEL Classification: F22, J61, L83

Reference: Přivara, A., Kiner, A. (2020). Immigrant Employment in the Slovak Hospitality Industry: Profiles, Experience, and Education. Journal of Tourism and Services, 20(11), 167-182. doi:10.29036/jots.v11i21.223

\section{Introduction}

Globalisation is one of the most significant processes shaping the world in the past decades, with the growing relationships and interdependence between the economies, cultures and political systems of the world's countries having a major impact on international affairs, largely driven by trade in goods and services, technology and investment flows, people and information. Because it is a phenomenon primarily impacting the movement of people, it is important to clarify the concept of migration in order to taken an approach toward globalisation because the term is often misinterpreted in general discourse and the public notoriously confuses concepts such as immigration and emigration. The International Organization for Migration (IOM) understands migration to mean the movement of people from the place where they have habitually resided either across a border or internally. Distinguished by the 


\section{JOURNAL OF TOURISM AND SERVICES}

Issue 21, volume 11, ISSN 1804-5650 (Online)

www.jots.cz

direction of movement, immigration is a person entering another country from the country where they have lived and emigration is when they leave that country (IOM, 2019).

This paper discusses the characteristics of the current state of immigration-related catering and accommodation services in Slovakia. "Slovakia has not been a traditional destination for migrants. It is a culturally homogenous country that has not been influenced by the dramatic growth of migration during the 20th century." (Vidová and Sika, 2018, p. 44) However, the 2004 enlargement of the European Union has sparked a higher influx of migrants to Slovakia, thus causing migration to receive more attention among researchers in various scientific disciplines. Notwithstanding, it is crucial that the topic raised here has not yet been published in Slovakia, as it would uniquely contribute to research into cross-border migrations.

Tourism has also become a critical component of national GDP and, according to the World Travel and Tourism Council (WTTC), this sector has accounted since 2007 for at least 2\% of Slovakia's GDP, hovering in this time around the 2018 figure of 2.6\% (WTTC, 2020). In 2019, Slovakia recorded a record number of visitors, almost 6.5 million. A total of 17,703,695 overnight stays were recorded in Slovakia in 2019, an almost 15\% rise compared to the previous year of 15,155,083 (Statistical Office of the Slovak Republic, 2020). Businesses and facilities operating in the restaurant, hotel and other touristrelated sectors are creating jobs and mostly employing people with no professional qualifications and prior experience. Other studies carried out in selected EU countries show foreign workers to be playing a major role in tourism (Janta et al., 2011; Devine et al., 2007; Zopiatis et al., 2014). It can be interpreted as the migrants opting to take these jobs from having been economically motivated and seeking to improve their own lives, as well as the situation of relatives they have left behind through remittances, one of the most significant sources of income for developing countries. This type of movement described here can be considered economic migration. It also involves the money migrants send home from abroad. Bringing benefits both to migrant families and their home countries, remittances are one of the consequences of migration (Jančíková, 2014, p.6).

This paper primarily concentrates on job seekers coming from other countries as it takes a closer look at their countries of origin, gender and previous experience in the hospitality industry. Their education is particularly stressed, with attention focused on the highest levels, with the intention of providing answers to the questions of whether they meet the educational criteria for the desired job position and whether they are not overqualified for it. First, the theoretical framework is defined for the issue to be researched along with an attempt to capture the current state in the home environment. This paper seeks to profile foreign job-seekers and discover whether they had qualifications vastly higher than what was required for the position they took in this sector, taking into account also their sex since current opinion indicates no likelihood between over-education of male and female workers (McGoldrick and Robst, 1996; Renes and Ridder, 1995, Larsen et al, 2018). The findings here could aid in avoiding unnecessary employment of immigrants in low-paid jobs for which they are obviously overqualified and enable them to utilise their education and the human capital potential they possessed when they came to Slovakia.

\section{Literature review, migration, and hospitality sector of Slovakia}

Slovakia's geographic location and its population's increasing standard of living in the wake of deepening poverty in some regions of the world are extremely important factors turning it not just into a transit country, but ultimately a destination for migrants, too. "Even though Slovakia had historically experienced emigration, the new socioeconomic situation developed both in Europe and Slovakia after 1989 brought a major turnaround. After many years of population declines due to emigration, Slovak Republic was now transforming itself into a country with a rising official migrant population as new foreign migration trends started to appear." (Divinský, 2007, p.8). There are several reasons why migrants 


\section{JOURNAL OF TOURISM AND SERVICES}

Issue 21, volume 11, ISSN 1804-5650 (Online)

www.jots.cz

choose to leave their native countries and a number of factors encouraging them in some extent to emigrate. The so-called "push factors" include conflicts, persecution, political instability, social inequalities and both poor employment and career opportunities. But there are also "pull factors" like the draw of a higher standard of living and better work (Lee, 1966). The data captured in Graph 1 show the number of immigrants rising since 2000. Although it would fall in 2004, "this extraordinary decrease was caused by an administrative correction and not by the sudden departure of part of the foreign population from Slovakia. In the autumn of 2004, there was a cleanup in registered alien files and a removal of duplicate cases that had appeared over the previous years." (Divinský, 2009, p.29)

\section{Graph 1: Number of immigrants in Slovakia}

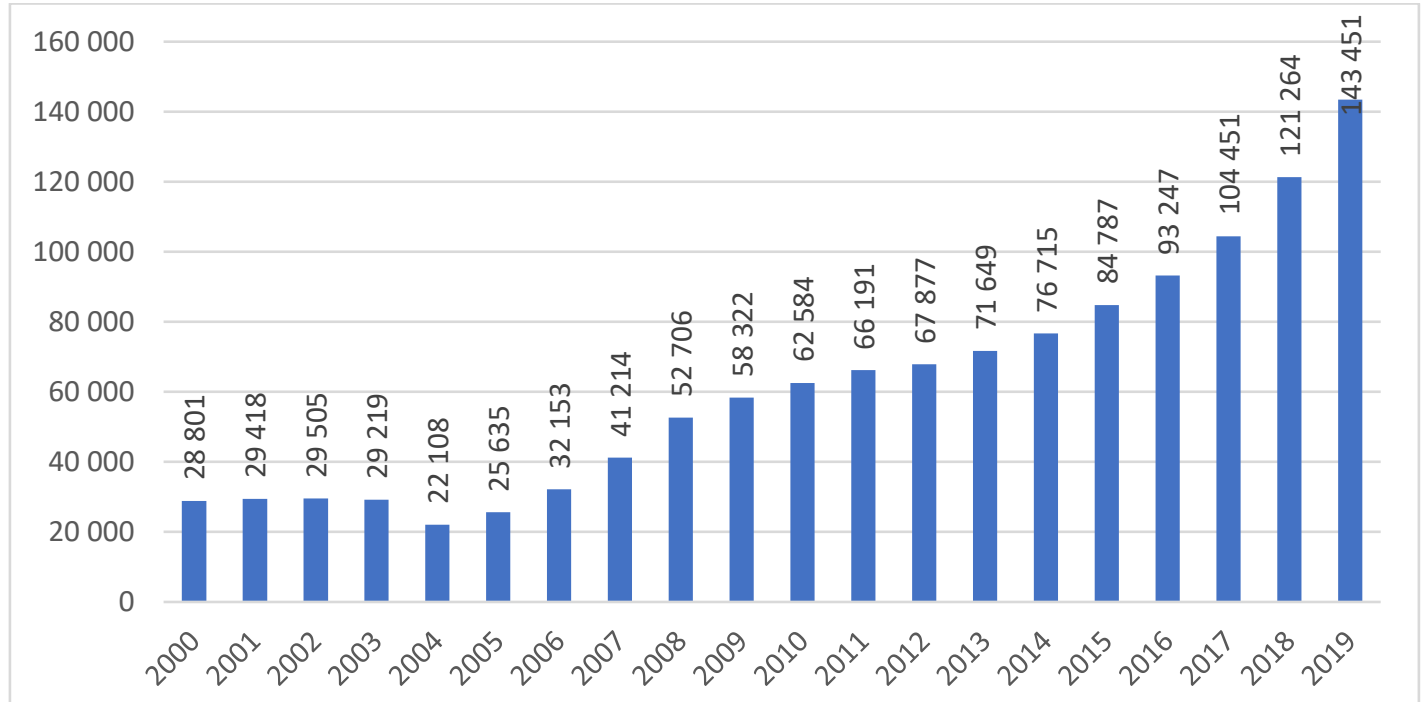

Source: Own proceedings according to Presidium of the Police Force, Bureau of Border and Foreigners Police

Several researchers from outside Slovakia have discussed migrants working in hotels, restaurants and other accommodation and catering facilities. Devine et al. researched migrant workers in Northern Ireland, seeking answers to questions about nationality, education, economic situation and country of origin. Their findings showed migrants mainly arriving for economic reasons as wages in their countries or origin ranged lower by several orders of magnitude (Devine et al., 2014).

The migrant situation was studied in Cyprus, where waves were heading soon after the country joined the EU during a period of its greatest demand for labour. Some of them that found their way into the hospitality industry faced abuse from their employers, primarily in the form of below-average wages and uncontrollable working conditions (Zopiatis et al., 2014). Further research showed many migrants entering the sector via seasonal or casual work to be often employed below the level of their qualifications (Baum, 2012). It can be concluded from the dual labour market theory that companies and their staff are divided into primary and secondary sectors. The primary sector satisfies basic demands in the economy and is composed essentially of larger companies better established in the labour market that provide higher-paying jobs. In contrast, the secondary sector responds to fluctuating or seasonal demand and relies mainly on cheap labour working in low-income jobs. The two-sector approach implies workmigration driven by demand in developed countries for labour cheaper than what is available domestically (Bean-Brown, 2015). Arguments have been made for closely linking the higher level of migrant employment in the tourism sector to reluctance among the local workforce to accept employment in such low-paid jobs, jobs with low social standing, or accept seasonal jobs (William and Hall, 2000; Monterrubio and Espinosa, 2013). Low salaries, a disagreeable management style and unsuitable scheduling of working hours also contribute to the high staff turnover found in the hotel industry (Vetráková et al., 2020), a 


\section{JOURNAL OF TOURISM AND SERVICES}

Issue 21, volume 11, ISSN 1804-5650 (Online)

www.jots.cz

finding concurred by Wright et al. (2019). Based on qualitative research in Australia, they found the local workforce not interested in jobs in the hospitality industry, with a preference for better paid positions elsewhere, forcing employers in the sector to turn to workers from outside of the country. Such a trend presents certain challenges for them to attract and retain employees and, over the long term, recruitment and training becomes costly and time-consuming (Janta and Ladkin, 2009). In light of such information, the belief that migrants are competing with local labour and taking away jobs becomes questionable.

When selecting a target country, migrants take their own human capital into account, which includes their education, experience, job and language skills and the work habits they have obtained from their country of origin. Migrants also choose a destination where they will be able to best apply this human capital (Chrančoková and Smrčková, 2015). Language skills are among the most common problems job-seeking immigrants encounter in a new country, as illustrated in the example of Poles coming to work in the United Kingdom (Janta et al., 2011). Analysing the relationship between human capital and wage levels for people employed in areas not demanding high skills, immigrants with higher education were found to be earning higher-percentage wages compared to those working in low-skill jobs. In addition, there was a positive effect on income from knowledge of the destination country's language (Hall and Farkas, 2008). Another study of education among immigrants living in the United States concluded that only $26 \%$ had acquired jobs corresponding to their level of education, with $45 \%$ undereducated and $29 \%$ overeducated. In comparison, $40 \%$ of the US work force was engaged in activities matching their qualifications (26\% undereducated and 33\% overeducated). Among highly qualified immigrants that had received the equivalent of a master's degree and/or university education, $79 \%$ were working in positions not matching their qualifications, compared to $70 \%$ of the domestic workforce (Chiswick and Miller, 2009). Another study of immigrants in the United Kingdom attributes the possible cause of this difference to devaluation of the qualifications and previous experience they had received in their home countries (Qureshi et al., 2011). Migrant workers across EU economies, and especially in the hotel sector, are often overqualified for the work they are to do. Eurostat (2011) noted foreign-born persons in 2008 experiencing significantly higher overqualification rates than nationals (34\% compared to 19\%) in the EU27. Based on the figures it could be considered that immigrants working in Slovakia will accordingly have skills available that exceed the requirements of the jobs they hold.

Based on immigration data and the number of tourists, a certain percentage of immigrants can be expected to be working in the services, accommodation and tourism sectors. According to the Statistical Office of the Slovak Republic, the number of foreign nationals working in these sectors has been growing since 2012 (prior to that year, there were no data about workers from foreign countries in Slovakia). Absolute numbers have been rising, although the proportion of foreigners from European countries and EU Member States, as well as from third countries, both with and without work permits has changed. These numbers for 2012-19 are displayed in the table below.

Table 1: Number of workers employed in trade, services and hospitality sector

\begin{tabular}{|c|c|c|c|c|c|c|c|c|}
\hline & $\mathbf{2 0 1 2}$ & $\mathbf{2 0 1 3}$ & $\mathbf{2 0 1 4}$ & $\mathbf{2 0 1 5}$ & $\mathbf{2 0 1 6}$ & $\mathbf{2 0 1 7}$ & $\mathbf{2 0 1 8}$ & $\mathbf{2 0 1 9}$ \\
\hline $\mathbf{3}^{\text {rd }}$ with wp & 606 & 521 & 384 & 424 & 504 & 672 & 964 & 1,690 \\
\hline EU $/$ EEA & 139 & 307 & 774 & 1,086 & 1,542 & 1,723 & 2,877 & 2,272 \\
\hline $\mathbf{3}^{\text {rd }}$ without wp & 79 & 119 & 223 & 322 & 442 & 753 & 1,127 & 1,701 \\
\hline All immigrants & $\mathbf{8 2 4}$ & $\mathbf{9 4 7}$ & $\mathbf{1 , 3 8 1}$ & $\mathbf{1 , 8 3 2}$ & $\mathbf{2 , 4 8 8}$ & $\mathbf{3 , 1 4 8}$ & $\mathbf{4 , 9 6 8}$ & $\mathbf{5 , 6 6 3}$ \\
\hline All workers & 594,029 & 588,573 & 599,520 & 603,993 & 610,744 & 621,575 & $\mathbf{6 3 2 , 7 9 2}$ & $\mathbf{6 3 2 , 9 1 1}$ \\
\hline
\end{tabular}

Source: Own proceedings according to Central Office of Labour, Social Affairs and Family 


\section{JOURNAL OF TOURISM AND SERVICES}

Issue 21, volume 11, ISSN 1804-5650 (Online)

www.jots.cz

According to the Statistical Office of the Slovak Republic, there has been a slight increase of workers employed in the trade, services, and hospitality industry in 2012 and 2019. The figures gathered from the statistics claim that in 2012 there were 594,029 employees. Since 2018 the total number of employees has remained approximately on the same level, and in 2019 we registered 632,911 workers. Based on the data we can conclude the share of migrant workers employed in the trade, service, and hospitality industry has been gradually increasing from $0.14 \%$ in 2012 up to almost $0.9 \%$ in 2019 . The most significant increase is observed between years 2017 and 2018, when migrants composed $0.51 \%$ and $0.79 \%$, respectively.

\section{Aim, methods, and data}

The purpose of this research study is to address a range of questions about migrant applicants in the hospitality sector in Slovakia. Specifically, this study seeks to seek information on the profile of migrant applicant, comprising their country of origin, level of education attained, previous experience from the hospitality industry, and to ascertain the degree of overqualification and assess possible variance between male and female applicants. Additionaly, the article endeavours to ascertain the interest of undergraduates working in the hospitality sector. In spite of not having attained full tertiary education, we consider undergraduates overqualified as well, since the hospitality industry does not require exacting skills, suggesting they can put acquired knowledge to good use in a post related to their study. Albrecht and Zemke identify three personalities factors that are important in the hospitality sector: an adequate level of self-esteem, social skills, and level of tolerance for social contact (Albrecht and Zemke, 1985). This statement is supported by Lashley who claims that most employers require little of students, but social skills and willingness to learn are desired (Lashley, 2011).

The article stems from a study examining immigrant applicants in Slovakia's hospitality sector. The data were gathered collecting and examining applicants' CVs as the selected technique enabled us to obtain desired information quickly and economically.

Thereby, our methods comprise a quantitative research in order to gain relevant insights of specific issues, and using netnography, a modern version of ethnography (Janta and Ladkin, 2009). The paper seeks to provide information on the profile of migrant applicants in the Slovak hospitality sector, specifically nationality, demographic characteristic, employment background, and mainly level of education. The research focuses on candidates, either full-timers and part-timers, who apply for the occupation of a waitperson, chef, cook, salesperson, barman, receptionist, room service waitperson and guide, however, the exact occupation preferences will not be stated as most candidates apply for various positions. The individual CVs were extracted from an internet Slovak recruiting and advertising platform Profesia.sk, which belongs to one of the most germane domains including both job advertisers and job seekers.

The study concerning CV analysis was conducted using data from June 24 to October 15, 2020. To achieve our objective, we filtered all CVs and limited our criteria to those applicants whose mother tongue was different from the Slovak. In addition, we took into consideration applicants' preference to a region in which they would like to be employed as we assume most applicants want to work in the capital of Slovakia. This might be reflected in, for instance, lower percentage of Ukrainians who are thought to seek a job in eastern region, thereby leading to irrelevant outcomes. Therefore, we kept a ratio "applicants per region" and based on the quotient we have examined selected sample of CVs according to 8 selfgoverning regions, which are Bratislava, Trnava, Nitra, Trenčín, Žilina, Banská Bystrica, Prešov and Košice region. We have analysed a total number of $493 \mathrm{CVs}$ out of 914 , which were chosen randomly in order to achieve maximal transparency and objectivity.

Since the hospitality industry is thought to employ a large number of immigrants, because it is considered a sector which is easy to enter due to little prerequisite of knowledge or skills required 


\section{JOURNAL OF TOURISM AND SERVICES}

Issue 21, volume 11, ISSN 1804-5650 (Online)

www.jots.cz

(Filimonau and Mika, 2017; Williams and Hall, 2000), the second part of the study sought an answer to hypotheses of whether they are overqualified for the desired occupation and whether overqualification applies equally regardless the sex of immigrants. The fact is that approximately one third of EU migrant hospitality workers is overqualified (Eurostat, 2011), thus we expect akin value in the context of Slovakia.

To prove or debunk the last hypothesis mentioned, we will analyse migrants' education profiles and those with tertiary education will be considered overqualified as the hospitality sector is perceived to be demanding low qualification. Besides, to investigate the possible variance between the variables "sex" and "overqualification" of male and female applicants' human capital we have used Pearson's chi-squared test with following formula:

$$
\chi^{2}=\sum \frac{(O-E)^{2}}{E}
$$

At this point, it is important to set $\mathrm{H} 0$ and $\mathrm{H} 1$ hypotheses:

H0: There is no significant difference between men's and women's level of overqualification.

H1: There is a significant difference between men's and women's level of overqualification.

Based on the Pearson's square test of independence we either confirm or reject null hypothesis. The level of significance is set at $\alpha=0.05$. "The degrees of freedom is dependent on the size of the table being studied, and can be calculated using the following simple formula [...] (\# Rows - 1)*(\# Columns 1)" (Walker, Ugoni, 1995, p. 63). Following the formula, the degree of freedom equals 1, thereby the critical value for chi square test at this degree of freedom, and level of significance $0.05(5 \%)$, is 3.841 (Dougherty, 2002, p. 9).

\section{Results}

Overall, there were 914 migrant applicants' CVs, of which 493 were examined. It follows that $53.94 \%$ of all CVs were subjected to examination. Results were analysed from applicants from Slovakia, the majority being from Bratislava region (BA), followed by Košice (KE), Prešov (PO) and Banská Bystrica region (BB). The minor immigrants' interest to work was registered in Trnava (TT), Nitra (NR), Zilina (ZA), and Trenčín region (TN). The following Table contains the collected data concerning sex of the migrant applicants ( $\mathrm{M}$ - man; $\mathrm{W}$ - woman), their highest level of education attained ( $\mathrm{P}$ - primary; $\mathrm{S}$ - secondary; $\mathrm{T}$ - tertiary education, including tertiary students), as well as their command of the Slovak language (SL) and any foreign language (FL) at level B2 or higher (Common European Framework of Reference for Languages). The overall number of tertiary educated applicants excluding undergraduates is stated in brackets. Moreover, the table also shows whether the applicants have gained experience related (rel) or unrelated (unr) to their desired occupation, and it also provides data regarding overqualification of men (OQ M) and women (OQ W). Last but not least, following table contains overall share of CVs according to the individual region (\%), and number of examined CVs (n).

\section{Table 2: Results of our investigation}

\begin{tabular}{|c|c|c|c|c|c|c|c|c|c|c|c|c|c|c|c|c|c|}
\hline & \multicolumn{2}{|c|}{ CVs } & \multicolumn{2}{|c|}{ Sex } & \multicolumn{3}{|c|}{ Education } & \multicolumn{2}{|c|}{ SL } & \multicolumn{2}{|c|}{ FL } & \multicolumn{2}{|c|}{ Exp } & \multicolumn{2}{|c|}{ OQ M } & \multicolumn{2}{|c|}{ OQ W } \\
\hline & $\%$ & $\mathrm{n}$ & $\mathrm{M}$ & W & $\mathrm{P}$ & S & $\mathrm{T}$ & yes & no & yes & no & rel & unr & yes & no & yes & no \\
\hline BA & 37.32 & 184 & 83 & 101 & 1 & 83 & $100(49)$ & 160 & 24 & 159 & 25 & 157 & 27 & $42(19)$ & 41 & $58(30)$ & 43 \\
\hline T'T & 9.74 & 48 & 22 & 26 & - & 20 & $28(8)$ & 39 & 9 & 41 & 7 & 42 & 6 & 15(4) & 7 & 13(4) & 13 \\
\hline NR & 6.29 & 31 & 12 & 19 & - & 14 & $17(6)$ & 25 & 6 & 27 & 4 & 23 & 8 & $7(2)$ & 5 & $10(4)$ & 9 \\
\hline $\mathrm{TN}$ & 1.83 & 9 & 2 & 7 & - & 2 & $7(3)$ & 9 & - & 9 & - & 8 & 1 & 1 & 1 & $6(3)$ & 1 \\
\hline
\end{tabular}




\section{JOURNAL OF TOURISM AND SERVICES}

Issue 21, volume 11, ISSN 1804-5650 (Online)

www.jots.cz

\begin{tabular}{|c|c|c|c|c|c|c|c|c|c|c|c|c|c|c|c|c|c|}
\hline ZA & 5.07 & 25 & 12 & 13 & - & 16 & $9(3)$ & 23 & 2 & 17 & 8 & 20 & 5 & $4(1)$ & 8 & $5(2)$ & 8 \\
\hline BB & 7.30 & 36 & 17 & 19 & - & 11 & $25(5)$ & 35 & 1 & 32 & 4 & 28 & 8 & $10(2)$ & 7 & $15(3)$ & 4 \\
\hline PO & 16.02 & 79 & 31 & 48 & - & 9 & $70(18)$ & 59 & 20 & 63 & 16 & 59 & 20 & $26(7)$ & 5 & $44(11)$ & 4 \\
\hline KE & 16.43 & 81 & 25 & 56 & - & 5 & $76(17)$ & 65 & 16 & 69 & 12 & 64 & 17 & $24(6)$ & 1 & $52(11)$ & 4 \\
\hline All & $\mathbf{1 0 0}$ & $\mathbf{4 9 3}$ & $\mathbf{2 0 4}$ & $\mathbf{2 8 9}$ & $\mathbf{1}$ & $\mathbf{1 6 0}$ & $\mathbf{3 3 2 ( 1 0 9 )}$ & $\mathbf{4 1 5}$ & $\mathbf{7 8}$ & $\mathbf{4 1 7}$ & $\mathbf{7 6}$ & $\mathbf{4 0 1}$ & $\mathbf{9 2}$ & $\mathbf{1 2 9 ( 4 1 )}$ & $\mathbf{7 5}$ & $\mathbf{2 0 3 ( 6 8 )}$ & $\mathbf{8 6}$ \\
\hline
\end{tabular}

Source: Own proceedings according to our findings.

By drawing on results from our research, we can observe that there were more female $(58,6 \%)$ than male $(41,4 \%)$ migrant applicants. Note that the age parameter is not included in the paper, as it will form part of further research. The ration between sexes fluctuates around the same level, nevertheless the eastern regions Prešov and Košice register more female applicants. The Table 3 contains data concerning country of destination of examined applicants and their CVs.

Table 3: Overview of immigrant applicants' countries of origin

\begin{tabular}{|c|c|c|c|c|c|c|c|c|c|}
\hline Country & $\mathrm{BA}$ & TT & NR & $\mathrm{TN}$ & ZA & $\mathrm{BB}$ & $\mathrm{PO}$ & $\mathrm{KE}$ & All \\
\hline Ukraine & 76 & 23 & 22 & 6 & 17 & 19 & 68 & 72 & 303 \\
\hline Serbia & 56 & 12 & 4 & 2 & 2 & 7 & 1 & - & 84 \\
\hline Poland & 3 & 2 & - & - & 1 & 1 & 2 & 1 & 10 \\
\hline Czechia & 15 & 1 & 1 & 1 & 2 & 4 & 1 & - & 23 \\
\hline Hungary & 8 & 4 & 1 & - & - & - & - & 5 & 18 \\
\hline Russia & 7 & 1 & 1 & - & 1 & 2 & 4 & 3 & 18 \\
\hline Belarus & 4 & 1 & - & - & 1 & 1 & 2 & - & 9 \\
\hline China & 2 & - & - & - & - & - & - & - & 2 \\
\hline Belgium & 2 & - & - & - & - & - & - & - & 2 \\
\hline Lebanon & 1 & - & - & - & - & - & - & - & 1 \\
\hline Dom. Rep. & 1 & - & - & - & - & - & - & - & 1 \\
\hline Turkey & - & 2 & - & - & - & - & - & - & 2 \\
\hline Egypt & 2 & 1 & - & - & - & - & - & - & 3 \\
\hline Mexico & 1 & - & 1 & - & - & - & - & - & 2 \\
\hline Italy & 2 & - & - & - & 1 & 2 & - & - & 5 \\
\hline Spain & 2 & - & 1 & - & - & - & - & - & 3 \\
\hline Vietnam & 1 & - & - & - & - & - & - & - & 1 \\
\hline Thailand & 1 & - & - & - & - & - & - & - & 1 \\
\hline Austria & 2 & & & & & & - & - & 1 \\
\hline Germany & 1 & & & & & & - & - & 1 \\
\hline Kazakhstan & - & - & - & - & - & - & 1 & - & 2 \\
\hline Albania & - & 1 & - & - & - & - & - & - & 1 \\
\hline All & 184 & 48 & 31 & 9 & 25 & 36 & 79 & 81 & 493 \\
\hline
\end{tabular}

The majority of in-migrants applying for a job in hospitality industry are Ukrainians (303), comprising $61.4 \%$ of all applicants. They are followed by Serbians, who account for $17 \%$ (84) of all job candidates. Beside, we register 4.7\% (23) of Czechs, 3.7\% (18) of Russians and Hungarians. Belarussians represent $1.8 \%$ (9) followed by $1 \%$ (5) of Italians, and the reminder is composed of nations with only 1-3 applicant/s. Share of Ukrainians is germane in all regions, but primarily in Prešov and Košice, while Serbians are mostly concentrated in western part of the country, in regions of Bratislava, Trnava, Nitra, and in the region of Banská Bystrica as well. 


\section{JOURNAL OF TOURISM AND SERVICES}

Issue 21, volume 11, ISSN 1804-5650 (Online)

www.jots.cz

Concerning immigrants and their attained level of education, we record solely applicants with secondary and tertiary education, except for one case with primary education only. The overall number of migrants with tertiary education greatly outnumbers those with secondary, significantly in Prešov and Košice region.

In addition to the maximal level of education attained, we also examined both command of Slovak and any foreign language at minimal level of B2. The results show the positive in favour of immigrants, since more than $84 \%$ master Slovak and other foreign language/s at given level. Considering the language proficiency, $84.2 \%$ of all applicant master the Slovak language, while $84.6 \%$ speak other foreign language/s. Regions which move below the nationwide average of the Slovak speaking applicants are Trnava (81.3\%), Nitra (80.6\%), Košice (80.2\%) and Prešov (74.7\%), while Bratislava (87\%), Žilina (92\%), Banská Bystrica $(97.2 \%)$ and Trenčín (100\%) scored more than the average. Lowest number of applicants mastering any foreign language is registered in Žilina (68\%), and Prešov region (79.7\%), putting them below the average. The highest number of foreign language speakers among applicants is recorded in Trenčín (100\%), followed by Banská Bystrica (88.9\%), Nitra (87.1\%), Bratislava (86.4\%), Trnava (85.4\%), and Košice $(85.2 \%)$.

We were also interested and wanted to find out whether they had had previous experience in hospitality industry. The findings of the analysis demonstrate that the majority of applicants $(81.3 \%)$ have already worked in hospitality sector, while $18.7 \%$ (92) of applicants will probably first meet with the hospitality industry for the first time. The highest share of those already having work experience from the sector apply for a job in Trenčín (88.9\%), Trnava (87.5\%) and Bratislava region (85.3\%), while in Nitra (74.2\%), Prešov (74.7\%), Banská Bystrica (77.8\%), Košice (79\%), and Žilina region (80\%).

From the data we have obtained it is clearly visible that 129 out of 204 men, and 203 out of 289, meaning $63.2 \%$ and $70.2 \%$ respectively, were overqualified, while $41(20 \%)$ male and $68(23.5 \%)$ female applicants attained university education. From the percentage results, it can be concluded that women are more likely to apply for the positions for which they are overqualified. The highest share of overqualified applicants is registered in Prešov and Košice region, where 88.6\% and 93.8\% of applicants possess knowledge that exceeds the minimal job requirements. These regions are followed by Trenčín $(77.8 \%)$ and Banská Bystrica region (69.4\%). On the other hand, Žilina is the only region in which the ratio of overqualified is below $50 \%(36 \%)$. Bratislava $(54.3 \%)$ and Nitra $(54.8 \%)$ are approximately on the same level concerning the share of the overqualified. Trnava (58.3\%) also belongs among regions, in which the share of the overqualified is below the nationwide average of $67.3 \%$. However, if we take into account graduates only, $19.3 \%$ of all applicants attained tertiary education.

Table 4: Distribution of overqualified applicants based on the nationality and region

\begin{tabular}{|l|c|c|c|c|c|c|c|c|c|c|}
\hline Country & BA & TT & NR & TN & ZA & BB & PO & KE & All & $\%$ \\
\hline Ukraine & $51(18)$ & $17(3)$ & $12(3)$ & $5(2)$ & $7(2)$ & $15(3)$ & $63(13)$ & $69(15)$ & $239(59)$ & $78.9(19.5)$ \\
\hline Serbia & $22(9)$ & $5(1)$ & $2(1)$ & 1 & 1 & 5 & - & - & $36(6)$ & $42.9(13.1)$ \\
\hline Poland & $2(2)$ & 1 & - & - & - & - & $1(1)$ & 1 & $5(3)$ & $50(30)$ \\
\hline Czechia & $7(5)$ & $1(1)$ & $1(1)$ & $1(1)$ & $1(1)$ & $2(1)$ & - & - & $13(10)$ & $56.5(43.5)$ \\
\hline Hungary & $2(1)$ & $1(1)$ & 1 & - & - & - & - & $3(1)$ & $7(3)$ & $38.9(16.7)$ \\
\hline Russia & $4(3)$ & 1 & - & - & - & 1 & $3(1)$ & $3(1)$ & $12(5)$ & $66.7(27.8)$ \\
\hline Belarus & $3(2)$ & - & - & - & - & 1 & $2(2)$ & - & $6(4)$ & $66.7(44.4)$ \\
\hline China & - & - & - & - & - & - & - & - & 0 & $0(0)$ \\
\hline Belgium & $2(2)$ & - & - & - & - & - & - & - & $2(2)$ & $100(100)$ \\
\hline Lebanon & $1(1)$ & - & - & - & - & - & - & - & $1(1)$ & $100(100)$ \\
\hline Dom. Rep. & $1(1)$ & - & - & - & - & - & - & - & $1(1)$ & $100(100)$ \\
\hline Turkey & - & $1(1)$ & - & - & - & - & - & - & $1(1)$ & $50(50)$ \\
\hline Egypt & $1(1)$ & $1(1)$ & - & - & - & - & - & - & $2(2)$ & $66.7(66.7)$ \\
\hline
\end{tabular}




\section{JOURNAL OF TOURISM AND SERVICES}

Issue 21, volume 11, ISSN 1804-5650 (Online)

www.jots.cz

\begin{tabular}{|l|c|c|c|c|c|c|c|c|c|c|}
\hline Mexico & $1(1)$ & - & $1(1)$ & - & - & - & - & - & $2(2)$ & $100(100)$ \\
\hline Italy & $1(1)$ & - & - & - & - & $1(1)$ & - & - & $2(2)$ & $40(40)$ \\
\hline Spain & $1(1)$ & - & - & - & - & - & - & - & $1(1)$ & $33.3(33.3)$ \\
\hline Vietnam & - & - & - & - & - & - & - & - & 0 & 0 \\
\hline Thailand & - & - & - & - & - & - & - & - & 0 & 0 \\
\hline Austria & $1(1)$ & - & - & - & - & - & - & - & $1(1)$ & $100(100)$ \\
\hline Germany & - & - & - & - & - & - & - & - & 0 & 0 \\
\hline Kazakhstan & - & - & - & - & - & - & $1(1)$ & - & $1(1)$ & $50(50)$ \\
\hline Albania & - & - & - & - & - & - & - & - & 0 & 0 \\
\hline All & $100(49)$ & $28(8)$ & $17(6)$ & $7(3)$ & $9(3)$ & $25(5)$ & $70(18)$ & $76(17)$ & $332(109)$ & $67.3(22.1)$ \\
\hline
\end{tabular}

The Table 4 shows the ratio between applicants with or without tertiary education (including undergraduates; number of graduates is stated in brackets). Considering only nationalities with at least 15 applicants, it stems from the table that the highest share of the overqualified come from Ukraine $(78.9 \%)$, Russia (66.7\%), Czechia (56.5)\%, Poland (50\%), Serbia (42.9\%) and Hungary (38.9\%), however, their distribution across regions varies. The major part of undergraduates and tertiary-educated Ukrainian migrant applicants is registered in eastern regions of Prešov and Košice, with more than $94 \%$ of the total number. On the other hand, the lowest share is recorded in Nitra (54.5\%) and Bratislava (67.1\%). As for the second most numerous nationality, Serbians, only $42.9 \%$ are considered overqualified. Excluding Prešov region (since there is only one Serbian applicant), Bratislava registers the lowest proportion of overqualified Serbian applicants, while on the contrary, the most numerous part apply for a job in Banská Bystrica region (71.4\%). If we disregard undergradutes and focus solely on those who attained any form of tertiary education, there is $19.5 \%$ of Ukrainians while only $13.1 \%$ of Serbians. Using Pearosn's coefficient, we identify a possible relationship between applicants' sex and overqualification:

Table 5: Observed values

\begin{tabular}{|l|c|c|c|}
\hline Observed & Overqualification & $\begin{array}{c}\text { Appropriate } \\
\text { qualification }\end{array}$ & All \\
\hline Man & 129 & 75 & 204 \\
\hline Women & 203 & 86 & 289 \\
\hline All & 332 & 161 & 493 \\
\hline
\end{tabular}

Source: Own proceedings according to our findings.

The next step consists in creating a contingency table bearing expected values. These are obtained as follows:
a) $332 * 204 / 493=137.38$
b) $161 * 204 / 493=66.62$
c) $332 * 289 / 493=194.62$
d) $161 * 289 / 493=94.38$

Table 6: Expected values

\begin{tabular}{|l|c|c|c|}
\hline Expected & Overqualification & $\begin{array}{c}\text { Appropriate } \\
\text { qualification }\end{array}$ & All \\
\hline Man & 137.38 & 66.62 & 204 \\
\hline Women & 194.62 & 94.38 & 289 \\
\hline All & 332 & 161 & 493 \\
\hline
\end{tabular}




\section{JOURNAL OF TOURISM AND SERVICES}

Issue 21, volume 11, ISSN 1804-5650 (Online)

www.jots.cz

Source: Own proceedings according to our calculations.

Having obtained the expected values, we compare them with what has been observed. Using the formula of Pearson's chi square test, we calculate values for each category:
a) $\frac{(129-137.38)^{2}}{137.38}=0.51$
b) $\frac{(75-66.62)^{2}}{66.62}=1.05$
c) $\frac{(203-194.62)^{2}}{164.62}=0.36$
d) $\frac{(86-94.38)^{2}}{94.38}=0.74$
$\chi^{2}=0.51+1.05+0.36+0.74=2.66$

Thus, the value of $\chi^{2}$ is approximately 2.66. Its value is smaller than 3.841 , therefore we have enough evidence and the null hypotheses can be confirmed, indicating there is no significant difference between sexes regarding overqualification. Immigrant applicants are more likely to be overqualified. However, in fact, the degree of their overqualification based on education is not higher than on the EU level, and there is no substantial difference between gender rather than difference across individual regions.

\section{Discussion}

Based on the findings we can conclude that female migrant applicants tend to seek a job in the hospitality industry. The same scenario can be observed in the capital of Norway, Oslo, with $60 \%$ female staff (Bråten et al., 2012). Lower participation of men applying for the positions concerning hospitality sector might be argued by higher interest in working in other sectors, predominantly in industrial production. The fact is that this sector employs by far most migrants coming to Slovakia (COLSAF, 2020), although we lack the information about male and female workers ratio. Thus, we assume women usually apply for posts which do not require physical strength.

Labour migrants who came to Slovakia after Slovakia's accession to the EU were characterized by a high number of education attainment and more than $50 \%$ of migrant workers had university education (Přívarová and Př́vara, 2015). In spite of the relatively high number, it is not as high as in the USA, where almost $80 \%$ of immigrants with university or higher education attained are overqualified. The profiles of hospitality immigrant applicants emerging from the study indicate high level of qualification of male and female applicants. The hospitality industry is considered as one requiring low qualification, therefore it is surprising that many undergraduates and people with university diploma are willing to work in the sector regardless their education. In spite of the high qualification, the case of Slovakia is not unique, since similar phenomenon might be observed across the globe (Janta, 2009; Chiswick and Miller, 2009; Qureshi et al., 2011). In case of Slovakia, 67.3\% of applicants willing to work in the hospitality sector are overqualified, suggesting we confirm out hypothesis and identify with academics discussed in the theoretical part, although the degree of overqualification varies. On the other hand, if we are to exclude undergraduates and focus solely on the tertiary-educated, $22.1 \%$ of all applicants have attained tertiary education and already graduated. Wadsworth et al. found that $44 \%$ of EU nationals working in the UK hospitality sector have some form of higher-education compared with 23\% of UK-born (Wadsworth et al., 2016). Other academic research suggests that migrant workers have higher levels of productivity and are often overqualified for their jobs (Adams et al., 2016). Similar results were obtained by Baum et al. (2007), claiming that $46.8 \%$ of the UK migrant hospitality employees 


\section{JOURNAL OF TOURISM AND SERVICES}

Issue 21, volume 11, ISSN 1804-5650 (Online)

www.jots.cz

attained university qualification, suggesting their overqualification (Baum et al., 2007). The overall number of the tertiary-educated in the hospilatily is lower than in the UK, but it turned out the sector is attractive for undergraduates.

The prime reason and willingness of taking up lower paid jobs while being over-educated might be the lack of recognition or devaluation of their qualification (Qureshi, 2011; Chiswick, 1978). Belot and Ederveen share the same idea, claiming that immigrants are discriminated by not recognising professional qualification acquired abroad (Belot and Ederveen, 2011). Another reason, which might contribute to this, is insufficient command of the language of host country. Under-skilling may reflect lower language proficiency which may not essentially affect migrants' performance at work (Perry, 2017). Undoubtedly, the language plays an important role, since both language and cultural distance can affect migrants' choice of country of destination (Kiner, 2020). Polish migrants working in the UK hospitality sector often face difficulties making themselves understood due to insufficient language competence (Janta, 2011). However, from our findings, suggesting most migrants master the Slovak language, the explanation for this must be something different. It can be concluded that migrant applicants possess appropriate knowledge of the Slovak and other foreign language/s, majority of them attained university education, making them overqualified for desired positions, although hospitality sector seems as the most easiest way to find a job as their previous job experience in this sector suggests. The fact is that migrants despite their qualification opt for low skilled jobs in the hope they can climb the occupational ladder and move to better jobs (Gautier, 2002). On the other hand, immigrants or ethnic minorities might be discriminated against in the about market (Piracha and Vadean, 2012). This is, from our point of view, very unlikely since The Anti-Discrimination Act, in force since 1 July 2004, creates adequate instruments for equal treatment of migrants and for active suppression of discrimination.

Our subgoal was to determine whether female workers are more overqualified than male workers. To prove or debunk our hypotheses we opted for Pearson's square test. As other academics suggest, there is no differential between gender and likelihood of overeducation (McGoldrick and Robst, 1996; Renes and Ridder, 1995). Based on our calculations we identify with previous statement, as there is sufficient evidence to conclude that the null hypothesis is true and alternative hypothesis can be rejected, meaning there is no significant difference between men and women.

The Slovak hospitality sector employs more than 630000 people, of which $0.79 \%$ are migrant workers. For comparison, UK data suggests that $12.3 \%$ of employees in the UK's hospitality sector are EU nationals, compared to $72.7 \%$ who are British nationals and $15.0 \%$ are nationals of the rest of the world (KPMG, 2017). In the context of Slovakia, the majority of applicants come from Ukraine. It is not a surprising fact, since they comprise a significant part of all immigrants living in Slovakia. For illustration, out of 143,451 immigrants, Ukrainians accounted for 26,7\% (38 307). Serbians, as it results from our findings, are the second most frequent immigrants. Their share of all immigrants residing in Slovakia is 11,6\% (16 604) (BBFP, 2019). We observe that individual nationalities are not distributed equally across Slovakia, as diverse spectrum of nationalities are interested in working the region of Bratislava, mainly in the capital of Slovakia. It is explicable as it is the region with highest GDP in Slovakia, and one of the highest within the EU, placing in 8th place (Eurostat, 2019). Higher concentration and prevalent part of Ukrainians preferably apply for a position in eastern regions of Slovakia, which can be explicated by gravitational theory of migration and geographical closeness of both eastern regions and Ukraine (Galanská, 2014; Kiner, 2020).

Hospitality is among the largest and fastest growing industries in the world. It requires a lot of staff as the demand for workers changes due to seasonality, suggesting workers are usually hired for a limited period. Salaries tend to be low because positions do not necessarily require high skills, and conditions are often difficult, including night shifts and weekend work. Therefore, jobs in the hospitality sector are not very attractive to the local population, especially in developed countries. Many migrant workers do not see the hospitality industry as a sector in which they want to build their careers, trying to move to other sectors of the host economy or return home. However, work often gives them the 


\section{JOURNAL OF TOURISM AND SERVICES}

Issue 21, volume 11, ISSN 1804-5650 (Online)

www.jots.cz

opportunity to send money home or to gain new language skills that can be useful later in their careers. As a result, they can return home and start their own hospitality business based on the skills they have acquired.

\section{Conclusion}

This article reports an exploratory study on immigrants applying for a position in hospitality sector in the context of the Slovak Republic. The paper sought to analyse their profiles regarding sex, countries of origin, skills and primarily qualification levels. Concerning maximal level of education attained, the paper strived to find an answer to hypothesis of whether there is a significant difference in overqualification between male and female immigrant hospitality applicants.

From the results obtained we conclude that majority of applicants came from Ukraine and Serbia, mainly due to close geographical and cultural distance and better economic situation.

The underpinning education level attained by international applicants is relatively excellent, suggesting a certain degree of overqualification relative to job requirements. The number of applicants speaking Slovak at level B2 and other foreign language/s is high and can interact with either domestic or international clientele, indicating that immigrants can be integrated in the country's labour market with ease. What is more, most applicants already possess experience relevant to hospitality sector. Based on our calculations and findings we claim that overqualification concerns male and female applicants evenly, indicating there is no germane difference between sexes regarding this matter.

To sum up, we conclude that migrant hospitality applicants are overqualified for such a work. In spite of an appropriate command of Slovak language and education attained, we hold an opinion that the applicants opt for such a job due to simplicity to enter hospitality labour market and having previous experience.

One of the complications we dealt with throughout the article compilation was relatively small number of applicants and CVs available, possibly due to unfavourable COVID-19 pandemic restrictions, resulting in a small research sample. As a consequence, we were obliged to extend the period of CV collection from intended one month into period exceeding three months of the date of CV publication. In addition, the data were collected during summer season, when demand for hospitality workers is higher compared to the rest of the year, resulting in possible higher number of seasonal workers. Another possible limit of the research might be a fact that not all immigrant applicants probably took an opportunity to use a service of the domain Profesia.sk and rather opted for other channels or neither. Another intricacy was that candidates could deliberately or unknowingly embellish their CV data, primarily with regard to language competence, in order to convince recruiters that they spoke Slovak or another foreign language at a given level, while the language level could be lower. In further research on this topic it would be desirable to obtain a larger research sample by combining various tools available, such as various job advertising domains and Central Office of Labour, Social Affairs and Family.

Additionally, it would be convenient to investigate not solely applicants, but also immigrants already employed in the hospitality industry and compare gathered results with profiles of native hospitality workers and analyse a degree of overqualification in both genders. Overall, it would be useful to combine quantitative with qualitative research in this area, for example to conduct interviews or focus groups. Therefore, presented research opportunities will form an object of our further investigation, while appealing to other academics for conducting a research on this topic.

This research was funded by Vega research project no. 1/0037/20: "New challenges and solutions for employment growth in changing socioeconomic conditions" and VEGA research project no. 1/0287/19 "Integration of immigrants in EU countries from the point of view of migration policies". 


\section{JOURNAL OF TOURISM AND SERVICES}

Issue 21, volume 11, ISSN 1804-5650 (Online)

www.jots.cz

\section{References}

1. Adams, L., Broughton, A., Cranney, M., Dobie, S., Marangozov, R., Markaki, Y., Sumption, M. (2016). Recruitment in Britain: Examining employers' practices and attitudes to employing UK-born and foreignborn workers. Equality and Human Roghts Commission Research report 104, 2016

2. Albrecht, K., Zemke, R. (1985). Service America!: Doing business in the new economy. Irwin Proffesional Pub

3. Baum, T. (2012). Migrant workers in the international hotel industry. ILO International Migration Paper No. 112.

4. Baum, T., Dutton, E., Karimi, S., Kokkranikal, J. (2007). Cultural diversity in hospitality work. Cross Cultural Management: An International Journal, 2007, 14(3), 229-239. https://doi.org/10.1108/09596110710729238

5. Bean, F., Brown, S. K. (2015). Demographic Analyses of Immigration. Migration Theory: Talking Across Disciplines. New York: Routledge. 2015.

6. Belot, M., Ederveen, S. (2011). Cultural barriers in migration between OECD countries. Journal of Population Economics. 2012, 25, 1077-1105. https://doi.org/10.1007/s00148-011-0356-x

7. Bråten, M., Andersen, R. K., Svalund, J. (2008). HMS-tilstanden i Norge 2007. Fafo-rapport 2008, $1-233$

8. Central Office of Labour, Social Affairs and Family (COLSAF). Retrieved October, 5, 2020, from: https://www.upsvr.gov.sk/buxus/generate_page.php?page_id=475017

9. Chiswick, B. (1978). The effect of Americanisation on the earnings of foreign-born men. Journal of Political Economy. 1978, 86, 897-921. https://doi.org/10.1086/260717

10. Chiswick, B. R., Miller, P. W. (2009). Educational Mismatch: Are High-Skilled Immigrants Really Working at High-Skilled Jobs and Price They Pay If They Aren't?. IZA Discussion Paper No. 4280. 2009, 55

11. Chrnčoková, M., Smrčková, J. (2015). Hodnotenie faktorov migrácie študentov pomocou modelov strukturálnych rovnic. Retrieved September, 31, 2020 from: https://www.researchgate.net/publication/292139707_HODNOTENIE_FAKTOROV_MIG RACIE_STUDENTOV_POMOCOU_MODELOV_STRUKTURALNYH_ROVNIC

12. Devine, F., Baum, T., Devine, A., Hearns, N. (2007). Cultural Diversity in Hospitality Work: the Northern Ireland Experience. Internatonal Journal of Human Management. 18(2). 2007, 333-349, https://doi.org/10.1080/09585190601102596

13. Divinský, B. (2007). Zahraničná migrácia v Slovenskej republike. Vývojové trendy od roku 2000. Bratislava

14. Divinský, B. (2009). Migračné trendy v Slovenskej republike po vstupe krajiny do EÚ (2004-2008). Bratislava: IOM Medzinárodná organizácia pre migráciu

15. Dougherty, C. (2002). Introduction to econometrics. Retrieved October, 12, 2020, from: https://home.ubalt.edu/ntsbarsh/business-stat/StatistialTables.pdf

16. Eurostat (2011). One in three foreign-born persons aged 25 to 54 overqualified for their job. Retrieved October, 24, 2020 from: https://ec.europa.eu/eurostat/en/web/products-press-releases/-/308122011-AP

17. Eurostat. (2019). Regional GDP per capita ranged from 31\% to 626\% of the EU average in 2017. Retrieved October, 16, 2020 from: https://ec.europa.eu/eurostat/documents/2995521/9618249/126022019-AP-EN.pdf/f765d183-c3d2-4e2f-9256-cc6665909c80

18. Filimonau, V., Mika, M. (2017). Return labour migration: an exploratory study of Polish migrant workers from the UK hospitality industry. Current Issues in Tourism, 357-378. https://doi.org/10.1080/13683500.2017.1280778

19. Galanská, N. (2014). Vybrané koncepty a teórie medzinárodnej migrácie a ich aplikácia na súčasné migračné toky. Almanach: Aktuálne otázky svetovej ekonomiky a politiky, 9(2), 20-39 


\section{JOURNAL OF TOURISM AND SERVICES}

Issue 21, volume 11, ISSN 1804-5650 (Online)

www.jots.cz

20. Gautier, P. (2002). Unemployment and search externalities in a model with heterogenous jobs and workers. Economica, 69(273), 21-40

21. Hall, M., Farkas, G. (2008). Does Human Capital Raise Earnings for Immigrants in the Low-Skill Labor Market?. Demography, 45(3), 619-639. https://doi.org/10.1353/dem.0.0018

22. International Organization For Migration (IOM). (2019). UN Glossary on Migration. 2019. Retrieved October, 2, 2020, from: https://publications.iom.int/system/files/pdf/iml_34_glossary.pdf

23. Jančíková, E. (2014). Vplyv remitencií na rozvoj ekonomík In: Almanach: Aktuálne otázky svetovej ekonomiky a politiky, 9(1), 5-23

24. Janta, H. (2011). Polish Migrant Workers in the UK Hospitality Industry: Profiles, Work Experience and Methods for Accessing Employment. International Journal of Contemporary Hospitality Management, 23(6), 803-819. https://doi.org/10.1108/09596111111153484

25. Janta, H., Brown, L., Lugosi, P., Ladkin, A. (2011). Migrant relationship and tourism employment. Annals of Tourism Research, 38(4), 1322-1343. https://doi.org/10.1016/j.annals.2011.03.004

26. Janta, H., Ladkin, A. (2009). Polish migrant labor in the hospitality workfore: Implications for recruitment and retention. Toursim, Culture \& Communication, 9, 5-15. https://doi.org/10.3727/109830409787556693

27. Kiner, A. (2020). Vybrané teoretické prístupy k migrácii a ich aplikácia na migračné toky srbských Slovákov smerujúcich na Slovensko. Ekonomické, politické a právne otázky medzinárodných vațahov 2020, 222-229

28. KPMG. (2017). Labour migration in the hospitality sector. A KPMG report for the British Hospitality Association

29. Laarsen, E. N., Rogne, A. F., Birkelund, G. E. (2018). Perfect for the Job? Overqualification of Immigrants and their Descendants in the Norwegian Labor Market. Social Inclusion, 6(3), 79-103

30. Lashley, C. (2011). Insights Into Employing Students in Hospitality Operations: A Study in Nottingham, United Kingdom. Journal of Hospitality and Tourism Management, 18(1), 18-25. https://doi.org/10.1375/jhtm.18.1.18

31. Lee, S. E. (1966). A theory of migration. In: Demography, 3(1), 47-57. http://dx.doi.org/10.17645/si.v6i3.1451

32. McGoldrick, K., Robst, J. (1996). Gender Differences in Overeducation: A test of the Theory of Differential Overqualification. The American Economic Review, 86(2), 280-284

33. Mohd Shariff, N., Zainol Abidin, A., Mohd Bukhari, A. M. (2019). International Migrant Workers in Tourism and Hospitality Industry, Langkawi, Malaysia: Does Their Demographic Profile Matter?. GeoJournal of Tourism and Geosites, 25(2), 349-357. http://doi.org/10.30892/gtg.25206364

34. Monterrubio, J. C., Espinosa, B. (2013). Characterisation of Ecotourism Employment in a Developing World Destination. GeoJournal of Tourism and Geosites, 1(11), 54-65

35. Perry, A. (2017). Are over-qualified immigrants mismatched according to their actual skills? An international comparison of labor market placement in OECD countries. GESIS papers, 17

36. Piracha, M., Vadean, F. (2012). Migrant educational mismatch and the labour market. IZA Discussion Papers, 6414, 1-28. https://doi.org/10.4337/9781782546078.00017

37. Presidium Of The Police Force, Bureau Of Border And Foreigners Police (BBFP). Statistical Overview of Legal and Illegal Migration in the Slovak Republic. Retrieved August, 31, 2020, from: https://www.minv.sk/?rocenky

38. Presidium Of The Police Force, Bureau Of Border And Foreigners Police (BBFP). (2019). Statistical Overview of Legal and Illegal Migration in the Slovak Republic 2019. Retrieved October, 15, 2020, 


\section{JOURNAL OF TOURISM AND SERVICES}

Issue 21, volume 11, ISSN 1804-5650 (Online)

www.jots.cz

https://www.minv.sk/swift_data/source/policia/hranicna_a_cudzinecka_policia/rocenky/rok _2019/2019-rocenka-UHCP_EN.pdf

39. Př́ivarová, M., Přívara, A. (2015). Migration policy of Slovak Republic: issues and challenges. Actual Problems of Economics, 10, 324-331

40. Qureshi, K., Varhese, V.J., Osella, F. (2013). Indian Punjabi skilled migrants in Britain: of brain drain and under-employment. Journal of Management Development, 32(2), 182-192. https://doi.org/10.1108/02621711311305683

41. Renes, G., Ridder, G. (1995). Are women overqualified. Labour Economics, 2(1), 3-18. https://doi.org/10.1016/0927-5371(95)80003-G

42. Statistical Office of the Slovak Republic (SO SR). Kapacity a výkony ubytovacich zariadeni v Slovenskej republike - ročné údaje. Retrieved October, 5, 2020, from: http://datacube.statistics.sk/\#!/view/sk/VBD_SLOVSTAT/cr2001rs/v_cr2001rs_00_00_00 -sk

43. Statistical Office of the Slovak Republic (SO SR). Zamestnanost' podla ekonomickeých cinnosti A10 domáci koncept. Retrieved October, 5, 2020, from: http://datacube.statistics.sk/\#!/view/sk/VBD_SK_WIN/nu1025rs/v_nu1025rs_00_00_00_s $\mathrm{k}$

44. Vetráková, M., Kubal’a, J. Cole, D. A., Pompurová, K. (2020). Causes of employee fluctuation and the need for stabilization in Slovak hotels. Enterpreneurship and sustainibility issues, 8(1), 332 346. https://doi.org/10.9770/jesi.2020.8.1(23)

45. Vidová, J., Sika, P. (2018). The impact of business education on the strength of migration flows. In: Sociálno-ekonomická revue, 16(2), 44-53

46. Wadsworth, J., Dhinra, S., Gianmarco, O., Van Reenen, J. (2016). Brexit and the Impact of Immigration on the UK. Centre for Economic Performance: London School of Economics

47. Walker, B. F., Ugoni, A. (1995). The Chi square test: an introduction. COMSIG Review, 4(3), 6164

48. Williams, A., Hall, C. M. (2000). Tourism and Migration: New Relationship between Production and Consumption. Tourism Geographies, 2(1), 5-27. https://doi.org/10.1080/146166800363420

49. Wright, Ch. F., Knox, A., Constantin, A. (2019). Using or abusing? Scrutinising employer demand for temporary skilled migrants in the Australian hospitality industry. Economic and Industrial Democracy, 1-23. https://doi.org/10.1177/0143831X18823693

50. WTTC. Retrieved October, 4, 2020, from: https://knoema.com/WTTC2019/world-travel-andtourism-council-data

51. Zopiatis, A., Constanti, P., Theocharous, A. L. (2014). Migrant labor in hospitality: The Cyprus experience. International Journal of Hospitality Management, 111-120. https://doi.org/10.1016/j.ijhm.2013.11.002

\section{Brief description of Author/Authors:}

\section{Ing. Andrej Př́ivara, PhD.}

Department of Social Development and Labor, Faculty of National Economy, University of Economics in Bratislava, Dolnozemská cesta 1/b, 85235 Bratislava 5, Slovakia, www.nhf.euba.sk. Andrej Pŕívara is an assistant professor at the Faculty of National Economy. He focuses on selected issues of EU social policy, flexicurity policies, labour market, migrant integration, and migration, using an interdisciplinary approach when approaching selected issues. His scientific specialization is reflected in research projects, such as, for instance, Horizon 2020 MAGYC. 


\section{JOURNAL OF TOURISM AND SERVICES}

Issue 21, volume 11, ISSN 1804-5650 (Online)

www.jots.cz

\section{Mgr. Andrej Kiner}

Department of International Economic Relations and Economic Diplomacy, Faculty of Internationals Relations, University of Economics in Bratislava, Dolnozemská cesta 1/b, 85235 Bratislava 5, Slovakia, www.fmv.euba.sk. Andrej Kiner is a doctoral student of the Faculty of International Relation. His scientific research is primarily focused on intercultural communication, international migration and integration, as well as foreign direct investments in correlation with selected economic indicators. 